\title{
Mekanisme Kompleks Sepsis dan Syok Septik
}

\author{
${ }^{1}$ Diana S. Purwanto, ${ }^{2}$ Dalima A.W. Astrawinata
}

${ }^{1}$ Bagian Biokimia Fakultas Kedokteran Universitas Sam Ratulangi Manado
${ }^{2}$ Departemen Patologi Klinik Fakultas Kedokteran Universitas Indonesia
Email: dianashintapurwanto@ unsrat.ac.id

\begin{abstract}
Sepsis and septic shock are still important medical problems. As sepsis progresses to septic shock, the risk of death increases significantly. Sepsis is a complex mechanism which can include infectious pathogen with its virulence factors, host response, inflammatory response, impaired coagulation system, and organ dysfunction. The complexity of the pathogenesis and pathophysiology of sepsis involves almost all types of cells, tissues, and organ systems.
\end{abstract}

Keywords: sepsis, septic shock

\begin{abstract}
Abstrak: Sepsis dan syok septik masih merupakan masalah medis yang penting. Seiring penjalanan sepsis menjadi syok septik, risiko kematian meningkat secara signifikan. Sepsis ialah mekanisme kompleks yang dapat meliputi patogen penyebab infeksi dengan faktor virulensinya, respon pejamu, respon inflamasi, sistem koagulasi yang terganggu, dan disfungsi organ. Kompleksnya patogenesis dan patofisiologi sepsis melibatkan hampir semua jenis sel, jaringan, dan sistem organ.
\end{abstract}

Kata kunci: sepsis, syok septik

Sepsis dan sepsis berat merupakan penyebab utama kematian pada pasien kritis yang dirawat di ruang perawatan intensif (intensive care units/ICU) di Amerika Serikat. ${ }^{1}$ Penelitian metaanalisis oleh Jawad et al. $^{2}$ mendapatkan bahwa insidens sepsis dalam populasi berkisar 22240 kasus per 100.000 orang, sepsis berat 13-300 kasus per 100.000 orang, dan syok septik 11 kasus per 100.000 orang, dengan angka kematian mencapai $30 \%$ untuk sepsis, 50\% untuk sepsis berat, dan $80 \%$ untuk syok septik.

Sampai saat ini sepsis dan syok septik masih merupakan tantangan besar bagi dunia kedokteran. Seiring penjalanan sepsis menjadi syok septik, risiko kematian meningkat secara signifikan. Setiap jam keterlambatan pemberian antibiotik telah terbukti meningkatkan angka kematian syok septik sebesar 7,6\%. Sebaliknya, pasien systemic inflammatory response syndrome (SIRS) non-infeksi yang salah didiagnosis sebagai sepsis, dapat secara tidak tepat diobati dengan antibiotik spektrum luas, sehingga menunda pengobatan inflamasi sistemik yang mendasari dan memberikan kontribusi untuk munculnya resistensi antibiotik. ${ }^{3}$

Kompleksnya patogenesis dan patofislogi sepsis melibatkan hampir semua jenis sel, jaringan, dan sistem organ. Dalam artikel ini dibahas definisi, etiologi, dan patogenesis/patofisiologi sepsis dan syok septik yang meliputi patogen penyebab infeksi dengan faktor virulensinya, respon pejamu, respon inflamasi, sistem koagulasi yang terganggu, dan disfungsi organ.

\section{Definisi}

Beberapa konferensi besar telah mendefinisikan sepsis, sepsis berat, dan syok 
septik. Pertama, pada tahun 1991 the American College of Chest Physicians and Society of Critical Care Medicine (ACCP/ SCCM) mengajukan konsep SIRS, sepsis, sepsis berat, dan syok septik. Kriteria SIRS meliputi: 1) suhu tubuh $>38^{\circ} \mathrm{C}$ atau $<36^{\circ} \mathrm{C}$ per oral; 2) frekuensi nadi $>90 \mathrm{kali} / \mathrm{menit}$; 3) frekuensi napas $>20 \mathrm{kali} / \mathrm{menit}$ atau $\mathrm{PaCO}_{2}<32 \mathrm{mmHg}$; 4) jumlah leukosit $>12.000 / \mu \mathrm{L}$ atau $<4.000 / \mu \mathrm{L}$ atau $>10 \%$ bentuk imatur (batang). Sekurangnya dua dari empat kriteria di atas harus terpenuhi untuk mendefinisikan SIRS. Meskipun SIRS sering terjadi karena infeksi, keadaan non-infeksi seperti luka bakar, pakreatitis akut, dan trauma, dapat juga menyebabkan SIRS. Kriteria di atas tidak memasukkan penanda biokimia, seperti C-reactive protein (CRP), prokalsitonin, atau interleukin (IL)-6, yang sering meningkat pada sepsis. Sepsis didefinisikan sebagai SIRS yang disertai infeksi yang terbukti atau dicurigai. Sepsis berat adalah sepsis yang disertai dengan satu atau lebih tanda disfungsi organ, seperti menurunnya fungsi ginjal, hipoksemia, dan perubahan status mental. Syok septik merupakan sepsis dengan perfusi abnormal dan hipotensi (tekanan darah sistolik $<90 \mathrm{mmHg}$ atau menurun $>40 \mathrm{mmHg}$ di bawah tekanan darah dasar (baseline) pasien tersebut atau tekanan arteri rata-rata $<70 \mathrm{mmHg}$ ) selama sekurang-kurangnya 1 jam meskipun telah dilakukan resusitasi cairan yang adekuat, atau sepsis yang membutuhkan vasopresor untuk mempertahankan agar tekanan darah sistolik tetap $\geq 90 \mathrm{mmHg}$ atau tekanan arteri rata-rata $\geq 70 \mathrm{mmHg}$. Peningkatan laktat serum menjadi tanda hipoperfusi jaringan dan syok septik. ${ }^{1,4,5}$

Pada tahun 2001, konferensi definisi sepsis internasional diselenggarakan oleh SCCM, the European Society of Intensive Care Medicine (ESICM), the American College of Chest Physicians (ACCP), the American Thoracic Society (ATS), dan the Surgical Infection Society (SIS). Konferensi ini masih tetap menggunakan definisi di atas, selain itu mengembangkan konsep sistem penderajatan untuk sepsis berdasarkan empat karakteristik terpisah yang disebut PIRO. Huruf P mewakili predisposisi, mengindikasikan faktor-faktor yang memengaruhi pasien terhadap terjadinya sepsis meliputi faktor genetik, lingkungan, dan kondisi komorbid. Huruf I mewakili infeksi, termasuk lokasi infeksi, sumber infeksi, dan jenis organisme. Huruf $\mathrm{R}$ mewakili respon terhadap adanya infeksi, termasuk timbulnya SIRS. Huruf O mewakili disfungsi organ, termasuk kegagalan sistem organ seperti sistem koagulasi. ${ }^{5}$

Definisi baru untuk sepsis dan syok septik telah direkomendasikan oleh SCCM/ ESICM dalam konsensus internasional ke-3 (Sepsis-3) pada tahun 2016. Sepsis didefinisikan sebagai disfungsi organ yang mengancam jiwa, disebabkan oleh ketidakmampuan respon pejamu terhadap infeksi. Disfungsi organ dapat diidentifikasi sebagai perubahan akut sebagai konsekuensi infeksi yang dirumuskan dalam skor sequential (sepsis-related) organ failure assessment (SOFA) $\geq 2$ (Tabel 1). Penekanan pada disfungsi organ yang mengancam jiwa konsisten dengan pandangan bahwa cacat seluler mendasari kelainan fisiologik dan biokimia sistem organ spesifik. Skor SOFA $\geq 2$ mencerminkan risiko mortalitas rata-rata $10 \%$ untuk pasien yang dirawat di rumah sakit dengan tersangka infeksi. Syok septik merupakan bagian dari sepsis dengan disfungsi peredaran darah dan selular/metabolik yang mendasari, dikaitkan dengan peningkatan risiko kematian. Pasien syok septik dapat diidentifikasi secara klinis yaitu sepsis dengan disertai hipotensi menetap yang membutuhkan vasopresor untuk mempertahankan agar tekanan arteri rata-rata $\geq 65 \mathrm{mmHg}$ dan konsentrasi laktat darah $>2 \mathrm{mmol} / \mathrm{L}(>18$ $\mathrm{mg} / \mathrm{dL}$ ) meskipun telah dilakukan resusitasi cairan yang adekuat. Risiko mortalitas pasien yang dirawat menjadi $>40 \%{ }^{6}$

\section{Etiologi}

Masuknya mikroba ke aliran darah bukan merupakan sesuatu yang mendasar terhadap timbulnya sepsis berat, karena infeksi lokal dengan penyebab bakteri yang menghasilkan produk patogen seperti eksotoksin, dapat juga memicu respon inflamasi 
Tabel 1. Skor sequential organ failure assessment (SOFA) ${ }^{6}$

\begin{tabular}{|c|c|c|c|c|c|}
\hline \multirow[t]{2}{*}{ Sistem } & \multicolumn{5}{|c|}{ Skor } \\
\hline & $\mathbf{0}$ & 1 & 2 & 3 & 4 \\
\hline $\begin{array}{l}\text { Respirasi } \\
\mathrm{PaO}_{2} / \mathrm{FIO}_{2}, \quad \mathrm{mmHg} \\
(\mathrm{kPa})\end{array}$ & $\begin{array}{l}\geq 400 \\
(53,3)\end{array}$ & $\begin{array}{l}<400 \\
(53,3)\end{array}$ & $\begin{array}{l}<300 \\
(40)\end{array}$ & $\begin{array}{l}<200(26,7) \text { dengan } \\
\text { bantuan alat respi- } \\
\text { rasi }\end{array}$ & $\begin{array}{l}<100(13,3) \text { dengan } \\
\text { bantuan alat respirasi }\end{array}$ \\
\hline $\begin{array}{l}\text { Koagulasi } \\
\text { Trombosit, } \\
\times 10^{3} / \mu \mathrm{L} \\
\end{array}$ & $\geq 150$ & $<150$ & $<100$ & $<50$ & $<20$ \\
\hline $\begin{array}{l}\text { Hati } \\
\text { Bilirubin, mg/dL } \\
(\mu \mathrm{mol} / \mathrm{L})\end{array}$ & $\begin{array}{l}<1,2 \\
(<20) \\
\end{array}$ & $\begin{array}{l}1,2-1,9 \\
(20-32) \\
\end{array}$ & $\begin{array}{c}2,0-5,9 \\
(33-101) \\
\end{array}$ & $\begin{array}{c}6,0-11,9 \\
(102-204) \\
\end{array}$ & $\begin{array}{l}\geq 12,0 \\
(\geq 204)\end{array}$ \\
\hline Kardiovaskular & $\begin{array}{l}\mathrm{MAP} \geq 70 \\
\mathrm{mmHg}\end{array}$ & $\begin{array}{l}\mathrm{MAP}<70 \\
\mathrm{mmHg}\end{array}$ & $\begin{array}{l}\text { Dopamin } \leq 5 \\
\text { atau } \\
\text { dobutamin } \\
\text { (semua }^{\text {dosis) }}{ }^{b} \\
\end{array}$ & $\begin{array}{l}\text { Dopamin } 5,1-15 \\
\text { atau } \\
\text { epinefrin } \leq 0,1 \\
\text { atau } \\
\text { norepinefrine } \leq 0,1^{b}\end{array}$ & $\begin{array}{l}\text { Dopamin }>15 \\
\text { atau } \\
\text { epinefrin }>0,1 \\
\text { atau } \\
\text { norepinefrine }>0,1^{b}\end{array}$ \\
\hline $\begin{array}{l}\text { Sistem saraf pusat } \\
\text { Skor Glasgow } \\
\text { Coma Scale }^{\mathrm{c}}\end{array}$ & 15 & $13-14$ & $10-12$ & $6-9$ & $<6$ \\
\hline $\begin{array}{l}\text { Ginjal } \\
\text { Kreatinin, mg/dL } \\
(\mu \mathrm{mol} / \mathrm{L}) \\
\text { Urine output, } \\
\text { mL/hari } \\
\end{array}$ & $\begin{array}{l}<1,2 \\
(110)\end{array}$ & $\begin{array}{c}1,2-1,9 \\
(110-170)\end{array}$ & $\begin{array}{c}2,0-3,4 \\
(171-299)\end{array}$ & $\begin{array}{c}3,5-4,9 \\
(300-440) \\
<500\end{array}$ & $\begin{array}{l}>5,0 \\
(440) \\
<200\end{array}$ \\
\hline
\end{tabular}

Keterangan: $\mathrm{FIO}_{2}=$ fraction of inspired oxygen, $\mathrm{MAP}=$ mean arterial pressure, $\mathrm{PaO}_{2}=$ partial pressure of oxygen

${ }^{b}$ dosis katekolamin diberikan dalam $\mu \mathrm{g} / \mathrm{kg} /$ menit selama sekurang-kurangnya $1 \mathrm{jam}$

${ }^{c}$ Skor Glasgow Coma Scale berkisar 3-15; skor yang tinggi menggambarkan fungsi neurologis yang lebih baik.

sistemik sehingga menimbulkan disfungsi organ di tempat lain dan hipotensi. Kultur darah yang positif hanya ditemukan pada sekitar 20-40\% kasus sepsis berat dan persentasenya meningkat seiring tingkat keparahan dari sepsis, yaitu mencapai 40$70 \%$ pada pasien dengan syok septik. Bakteri Gram negatif atau positif mencakup sekitar $70 \%$ isolat, dan sisanya ialah jamur atau campuran mikroorganisme. Pada pasien dengan kultur darah negatif, agen penyebab sering ditegakkan berdasarkan kultur atau pemeriksaan mikroskopik dari bahan yang berasal dari fokus infeksi. ${ }^{7}$

Sepsis berat terjadi sebagai akibat dari infeksi yang didapat dari komunitas dan nosokomial. Pneumonia ialah penyebab paling umum, mencapai setengah dari semua kasus, diikuti oleh infeksi intraabdominal dan infeksi saluran kemih. Staphylococcus aureus dan Streptococcus pneumoniae ialah bakteri Gram positif paling sering, sedangkan Escherichia coli,
Klebsiella spp, dan Pseudomonas aeruginosa predominan di antara bakteri Gram negatif. $^{8}$

\section{Patogenesis dan Patofisiologi Faktor virulensi patogen}

Sepsis timbul akibat respon pejamu terhadap infeksi, yang diarahkan untuk mengeliminasi patogen. Patogen memiliki mekanisme atau faktor virulensi yang bervariasi sehingga memungkinkan patogen untuk bertahan dalam tubuh pejamu dan menyebabkan penyakit. Faktor virulensi menyebabkan patogen mampu menghambat fagositosis, memfasilitasi adhesi ke sel atau jaringan pejamu, meningkatkan survival intrasel setelah difagosit, dan merusak jaringan melalui produksi toksin dan enzim ekstrasel. ${ }^{9}$

Kapsul menghambat fagositosis terutama dengan cara menutupi struktur permukaan sel sehingga tidak dikenali oleh reseptor sel fagosit. Bakteri berkapsul seperti 
Streptococcus pneumoniae dan Haemophilus influenza dihubungkan dengan infeksi yang sangat invasif dan lebih virulen dibanding bakteri tidak berkapsul. Struktur lain berupa protein A, seperti pada dinding sel Staphylococcus aureus, menghambat ikatan antibodi pejamu terhadap permukaan patogen (sebagai antigen). Antibodi mengikat antigen melalui bagian Fab, protein A mengikat bagian Fc antibodi sehingga menghambat opsonisasi dan fagositosis. Beberapa patogen menghindari fagositosis dengan cara melepaskan produk poten di jaringan yang dapat membunuh sel fagosit. Streptococci memroduksi hemolisin yang melisiskan eritrosit dan merangsang efek toksik pada leukosit dan makrofag. Staphylococcus melepaskan leukocidin yang menyebabkan pelepasan lisosom ke dalam sitoplasma. ${ }^{9,10}$

Kebanyakan patogen harus menempel pada sel pejamu sebelum terjadi infeksi. Struktur permukaan sel patogen yang memediasi penempelan disebut adhesin, contohnya fimbriae (pili) dan lipoteichoic acid (LTA) pada bakteri. Fimbriae membuat bakteri melekat pada permukaan sel pejamu, sehingga meningkatkan kemampuan patogen untuk kolonisasi. Fimbriae digunakan oleh Neisseria gonorrhoeae untuk melekat pada sel epitel traktus genitourinarius. Strain Escherichia coli juga menggunakan fimbriae untuk melekat pada sel usus halus, sehingga nantinya mengeluarkan toksin yang menyebabkan gejala diare. Streptococcus pyogenes memiliki LTA yang terintegrasi pada peptidoglikan tebal untuk melekat pada sel epitel faring. ${ }^{9}$

Beberapa patogen berkemampuan untuk bertahan dan memperbanyak diri dalam sel fagosit setelah difagosit, dengan cara mencegah fusi fagosom dan lisosom (fagolisosom), bertahan terhadap efek dari isi lisosom, atau keluar dari fagosom ke dalam sitoplasma. Sebagai contoh, Mycobacterium tuberculosis dan Legionella pneumophila mencegah pembentukan fagolisosom, Mycobacterium leprae menginaktivasi reactive oxygen species (ROS) dan nitrogen species, dan Listeria monocytogenes merusak membran fagosom dan keluar ke sitoplasma. ${ }^{11}$

Kemampuan patogen untuk menghasilkan toksin (eksotoksin atau endotoksin) merupakan faktor utama lainyang berperan terhadap virulensi dan invasi patogen. Eksotoksin diproduksi terutama oleh bakteri Gram positif, dan disekresi ke lingkungan ekstrasel bakteri sehingga daat berinteraksi dengan sel pejamu dan mengganggu metabolisme normalnya. Sebagai contoh, Corynebacterium diphtheriae mengeluarkan toksin difteri yang bekerja menghambat sintesis protein, sehingga terjadi nekrosis sel-sel jantung, saraf, dan hati. Streptococcus pyogenes memroduksi streptolysin O yang merusak membran sel, menyebabkan faringitis. Toksin Vibrio cholerae menyebabkan peningkatan cyclic adenosine monophosphate (cAMP) pada sel epitel usus, sehingga terjadi diare karena hipersekresi klorida dan air. Di satu sisi, endotoksin diproduksi oleh bakteri Gram positif dan negatif. Bakteri Gram negatif memroduksi lipopolisakarida (LPS) yang menyusun membran luar bakteri dan terdiri atas 3 regio, yaitu polisakarida spesifik-O, polisakarida inti, dan lipid A. Aktivitas toksin dari endotoksin terdapat pada lipid A. Paparan terhadap endotoksin dapat menyebabkan efek yang sistemik, seperti perubahan tekanan darah dan suhu tubuh, abnormalitas koagulasi, penurunan jumlah sel leukosit dan trombosit yang bersirkulasi, perdarahan, gangguan sistem imun, dan akhirnya kematian., ${ }^{9,10}$

\section{Respon Pejamu}

Terdapat dua mekanisme pertahanan tubuh terhadap patogen yaitu respon imun bawaan dan didapat. Respon imun bawaan berespon secara cepat melalui reseptor selular dan solubel yang disebut sebagai pattern-recognition receptor (PRR). Reseptor selular diekpresikan pada membran dan sitoplasma oleh hampir semua sel terutama sel fagosit (terutama makrofag dan neutrofil) dan sel dendritik. Empat kelompok penting PRR adalah Toll-like receptor (TLR), nucleotide oligomerization domaincontaining protein-like receptors (NLRs), C-type lectin-like receptors (CLRs), dan 
retinoid acid-inducible gene-like receptors (RLRs). Pattern-recognition receptor mengenali struktur molekul yang khas untuk mikroorganisme patogen yaitu pathogenassociated molecular patterns (PAMPs), dan molekul endogen yang diproduksi atau dilepaskan dari sel yang rusak yaitu damage-associated molecular patterns (DAMPs). Contoh interaksi PRR dan PAMPs ialah TLR2 berikatan dengan LTA dari bakteri Gram positif, TLR4 berikatan dengan LPS dari bakteri Gram negatif, dan NLRs berikatan dengan peptidoglikan dari bakteri Gram positif dan DAMPs. ${ }^{12}$

Molekul solubel berperan pada respon awal terhadap mikroorganisme patogen yang berada di aliran darah dan cairan ekstraselular lainnya. Komponen molekul solubel utama adalah sistem komplemen, pentraxins, collentins, dan ficolins. Molekul solubel dapat berperan sebagai opsonin melalui ikatan dengan mikroorganisme, sehingga memudahkan sel fagosit yang memiliki reseptor membran spesifik terhadap opsonin, untuk memfagosit patogen tersebut. Selain itu, molekul solubel dapat bersifat kemoatraktan yang akan merangsang respon inflamasi dengan menarik lebih banyak sel fagosit ke lokasi infeksi dan langsung mengeliminasi patogen tersebut. Contoh peran molekul solubel yaitu aktivasi sistem komplemen pada jalur alternatif. Secara normal, komplemen C3 di plasma teraktivasi terus menerus dalam tingkat rendah menghasilkan C3b. Saat ada mikroorganisme patogen, $\mathrm{C} 3 \mathrm{~b}$ bisa mengenali struktur permukaan mikroorganisme seperti LPS untuk selanjutnya mengaktivasi jalur alternatif sistem komplemen. Fragmen C3a dan C5a yang bersifat kemoatraktan akan menarik lebih banyak fagosit ke lokasi infeksi. Contoh lain, protein kelompok pentraxins seperti $C$-reactive protein (CRP) mengenali ligan phosphorylcholine yang terdapat pada membran bakteri, selanjutnya berikatan dengan $\mathrm{Clq}$ dan mengaktivasi jalur klasik sistem komplemen. ${ }^{12}$

Respon imun didapat melibatkan sejumlah besar sel efektor dan molekul antibodi yang berfungsi untuk eliminasi patogen, dan sel memori yang melindungi pejamu dari infeksi berulang. Respon imun didapat melawan bakteri intrasel melibatkan sel limfosit $\mathrm{T}$ dan aktivasi sel fagosit (cell-mediated immunity). Sel $\mathrm{T}$ melawan infeksi melalui 2 cara, yaitu pertama sel $\mathrm{T}$ helper (CD4+) mengaktivasi sel fagosit melalui aksi ligan CD40 dan interferon gamma (IFN- $\gamma$ ), menyebabkan matinya bakteri yang bertahan dan memperbanyak diri dalam sel fagosit, dan kedua sel T sitotoksik (CD8+) menghancurkan sel terinfeksi termasuk mengeliminasi bakteri di dalamnya. Terhadap bakteri ekstrasel respon imun melibatkan antibodi terhadap antigen dinding sel dan toksin bakteri. Antibodi berperan melalui mekanisme neutralisasi, opsonisasi, dan aktivasi komplemen melalui jalur klasik. ${ }^{11}$

\section{Respon Inflamasi}

Terdapat tiga fase respon inflamasi dalam sepsis: 1) pelepasan toksin bakteri; 2) pelepasan mediator (sitokin) sebagai respon terhadap infeksi; dan 3) efek dari mediator spesifik yang berlebihan. Pada fase 1, bakteri Gram negatif dan positif mampu menyebabkan sepsis melalui endotoksin dan eksotoksin. Bakteri Gram negatif memiliki LPS sebagai endotoksin. Lipopolisakarida-binding protein (LBP) yang bersirkulasi di darah dan cairan ekstrasel, mengikat lipid A (bagian yang bersifat bioaktif pada LPS) dan membawa LPS ke cluster of differentiation14 (CD14) pada monosit, makrofag, dan neutrofil. Interaksi antara kompleks LBP-LPS dan reseptor CD14, memungkinkan LPS berikatan dengan TLR4, sehingga menimbulkan sinyal untuk dihantarkan ke inti sel, untuk selanjutnya merangsang produksi dan pelepasan mediator inflamasi. Bakteri Gram positif memiliki LTA dan muramyl dipeptides (MDP) sebagai endotoksin dan superantigen sebagai eksotoksin. ${ }^{13}$

Superantigen adalah keluarga protein eksotoksin dengan struktur dan rantai tertentu yang mampu mencetuskan aktivasi sel $\mathrm{T}$ berlebihan. Superantigen sebagai protein utuh akan terikat secara langsung ke molekul major histocompatibility complex (MHC) kelas II dari antigen 
precenting cell (APC) dan ke regio $\mathrm{V} \beta$ reseptor sel $\mathrm{T}$, tanpa melalui proses fragmentasi menjadi peptida di dalam APC. ${ }^{14}$ Jika LPS membutuhkan LBP untuk berikatan dengan TLR4, sebaliknya LTA dapat langsung berikatan dengan TLR2. ${ }^{13}$

Pada fase 2, interaksi antara PRR dan PAMPs menyebabkan aktivasi nuclear factor kappa $B(\mathrm{NF}-\kappa \mathrm{B})$, suatu faktor transkripsi yang memicu sintesis dan pelepasan berbagai sitokin pro-inflamasi seperti tumor necrosis factor- $\alpha$ (TNF- $\alpha$ ), interleukin-1 (IL-1 $\beta$ ), IL-6, dan CXCL-8 (IL-8). Sitokin TNF- $\alpha$ dan IL-1 mengaktifkan endotel dan menyebabkan endotel meningkatkan ekspresi molekul adhesi seperti selektin-E, intracellular adhesion molecule-1 (ICAM-1), dan vascular cell adhesion molecule-1 (VCAM-1) sebagai ligan untuk integrin dari leukosit. Selain itu, TNF- $\alpha$ dan IL-1 meningkatkan sekresi kemokin seperti CXCL1 yang akan terikat pada reseptornya di neutrofil, dan CCL2 di monosit, sehingga meningkatkan afinitas intergrin leukosit terhadap ligannya, dan meningkatkan migrasi leukosit. Sitokin TNF- $\alpha$, IL-1, dan IL-6 juga menginduksi hati untuk mengekspresikan protein fase akut seperti CRP, serum amyloid P (SAP), dan fibrinogen. ${ }^{12}$ Superantigen mengaktifkan limfosit $\mathrm{T}$ dan merangsang produksi IL-2 dan IFN- $\gamma$. Interleukin-2 adalah sitokin proinflamasi yang berperan dalam proliferasi dan diferensiasi limfosit $\mathrm{T}$ naive menjadi limfosit $\mathrm{T}$ efektor. Interferon- $\gamma$ berperan penting dalam imunitas yang dimediasi sel terhadap mikroba intrasel, mengaktivasi inducible nitric oxide synthase (iNOS), dan meningkatkan migrasi leukosit. Selain itu, IL-2 dan IFN- $\gamma$ memicu makrofag untuk melepaskan TNF$\alpha$ dan IL-1. ${ }^{13,14}$

Pada fase 3, sitokin proinflamasi mengaktifkan sel endotel dengan meninkatkan ekspresi reseptor adhesi dan menyebabkan kerusakan sel endotel dengan menginduksi adhesi neutrofil, monosit, makrofag, dan trombosit ke sel endotel. Sel-sel efektor ini melepaskan mediator seperti protease, oksidan, prostaglandin, dan leukotrien, yang akan merusak endotel sehingga menyebabkan peningkatan permeabilitas, vasodilatasi, dan gangguan keseimbangan prokoagulan-antikoagulan. Peningkatan aktivitas iNOS meningkatkan sintesis berlebihan nitrikmoksida (NO), yaitu suatu vasodilator poten dan merupakan mediator kunci pada syok septik. ${ }^{15}$

\section{Abnormalitas Koagulasi}

Pada sepsis dan syok septik, keadaan antikoagulasi normal dalam sistem pembuluh darah menjadi terganggu. Sepsis menyebabkan keadaan hiperkoagulabilitas yang ditandai oleh pembentukan trombus mikrovaskular, deposisi fibrin, pembentukan neutrophil extracellular trap (NET), dan kerusakan endotel. ${ }^{4}$ Keadaan di atas terjadi melalui beberapa mekanisme yang saling terkait, dengan melibatkan pelepasan sitokin pro-inflamasi (IL-1, IL-6, IL-12, dan TNF- $\alpha$ ), yaitu induksi ekspresi faktor jaringan (tissue factor - TF), penurunan kadar antitrombin, penghambatan faktor anti-koagulan, dan gangguan fibrinolisis. Sitokin pro-inflamasi menginduksi ekspresi berlebihan TF pada permukaan sel endotel dan monosit, menyebabkan interaksi $\mathrm{TF}$ dengan faktor VIIa, sehingga mengaktivasi koagulasi jalur ekstrinsik, pembetukan trombin, dan fibrin. Fibrin yang terbentuk, bersama dengan trombosit akan membentuk trombus mikrovaskular. Selain itu, permukaan bakteri Gram negatif dan positif dapat berinteraksi dengan faktor kontak dan mengaktivasi koagulasi jalur intrinsik melalui faktor XII. ${ }^{15,16}$ Sebagai contoh, Streptococcus pyogenes memiliki protein M (serotipe M1 dan M46) yang akan terikat pada faktor pembekuan high molecular weight kininogen (HK). Contoh lain, Escherichia coli memiliki curli, suatu komponen protein utama dari kompleks matriks ekstrasel, terikat pada HK, F.XII, F.XI, dan prekalikrein (PK). ${ }^{17}$

Secara normal, sebagai respon terhadap koagulasi yang terbentuk, faktor antikoagulan seperti protein $\mathrm{C}$, protein $\mathrm{S}$, antitrombin III (AT III), dan tissue factorpathway inhibitor (TFPI) akan mengurangi koagulasi, meningkatkan fibrinolisis, dan membersihkan mikrotrombus. Trombin 
dengan adanya kofaktor trombomodulin yang dikeluarkan oleh sel endotel, meningkatkan aktivasi protein $\mathrm{C}$ menjadi protein $\mathrm{C}$ aktif. Protein $\mathrm{C}$ aktif, dengan adanya kofaktor protein $\mathrm{S}$, akan memecah F.Va dan F.VIIIa menjadi bentuk yang tidak aktif, dan menurunkan sintesis plasminogen activator inhibitor-1 (PAI-1), yaitu suatu inhibitor yang bekerja terhadap aktivator plasminogen. Protein $\mathrm{C}$ aktif juga menurunkan apoptosis, adhesi leukosit, dan produksi sitokin. ${ }^{15}$ Peran protein $\mathrm{C}$ aktif menurunkan apoptosis sel endotel melalui penekanan dua gen pro-apoptosis, yaitu calreticulin dan TRMP-2, suatu protein retikulum endoplasma, sebaliknya meningkatkan gen anti apoptosis seperti $\mathrm{Al} \mathrm{Bcl-2}$ homologue, $G u$ helicase, dan inhibitor of apoptosis protein (IAP). ${ }^{18}$ Protein $\mathrm{C}$ aktif menghambat adhesi leukosit yang diperantarai oleh selektin-E, melalui struktur karbohidrat polylactosamine protein $\mathrm{C}$ yang lebih poten sebagai ligan selektin-E dibanding sialyl-Lewis $X$ (diekspresikan oleh granulosit dan monosit). ${ }^{19}$ Protein C aktif mengurangi produksi TNF oleh monosit akibat stimulasi LPS, dengan cara menghambat faktor transkripsi nuclear factor kappa-light-chain-enhancer of acti-

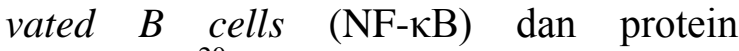
aktivator- $1 .^{20}$

Antitrombin III menghambat aktivitas trombin, selain itu juga menghambat F.XIIa, F.XIa, F.Xa, F.IXa, F.VIIa, plasmin, dan kalikrein. Koagulasi yang diinduksi TF dapat dihambat oleh TFPI, melalui pembentukan kompleks TFPI dengan F.Xa pada awalnya, dan selanjutnya mengikat kompleks F.VIIa-TF sehingga terbentuk kompleks kuartener. Sekali hal ini terjadi, maka F.Xa hanya akan terbentuk melalui kompleks F.IXa-F.VIIIa. ${ }^{21}$

Sepsis akan menurunkan protein $\mathrm{C}$, protein S, AT III, dan TFPI, sebaliknya akan meningkatkan sintesis dan aktivitas PAI-1 dan menurunkan aktivitas plasmin. Plasminogen activator inhibitor-1 merupakan protein fase akut positif yang disintesis oleh hepar sebagai respon terhadap infeksi/inflamasi. Lipopolisakarida dan TNF- $\alpha$ menurunkan sintesis trombomo- dulin dan reseptor protein $\mathrm{C}$ endotel (endothelial protein $C$ receptor - EPCR) sehingga menurunkan aktivasi protein $\mathrm{C}$, yang pada akhirnya menurunkan fibrinolisis. ${ }^{15}$ Kadar AT III sangat menurun karena beberapa faktor, yaitu sintesis hepar berkurang terhadap protein fase akut negatif ini, konsumsi karena pembentukan kompleks trombin-AT III, dan degradasi oleh elastase dari neutrofil yang teraktivasi. ${ }^{16}$

Aktivasi koagulasi pada sepsis dapat terjadi dari derajat ringan sampai berat, yaitu terjadinya disseminated intravascular coagulation (DIC). Transisi dari keadaan hiperkoagulabilitas menjadi DIC ditandai dengan fibrinolisis yang disertai peningkatan fibrin degradation products (FDP) di sirkulasi, trombositopenia, dan sangat berkurangnya faktor-faktor pembekuan akibat konsumsi berlebihan yang tidak dapat diimbangi oleh kecepatan produksinya. ${ }^{4}$

\section{Disfungsi Organ}

Terjadinya deposisi fibrin mikrovaskular pada DIC sering dihubungkan dengan berkembangnya disfungsi multi organ (multiorgan dysfunction syndrome MODS) yang disebabkan oleh gangguan sirkulasi. Multiorgan dysfunction syndrome didefinisikan sebagai sindrom klinis yang ditandai dengan perkembangan disfungsi fisiologis yang progresif dari ringan sampai kegagalan ireversibel dari dua atau lebih organ, dengan ditandai ketidakmampuan mempertahankan homeostasis tanpa intervensi terapi. Multiorgan dysfunction syndrome diklasifikasikan menjadi awal (primer), yaitu yang terjadi dalam 7 hari pertama sakit, dan lambat (sekunder), yang terjadi setelah 7 hari sakit. ${ }^{22}$

Gangguan oksigenasi jaringan dianggap berperan penting terhadap terjadinya MODS. Faktor yang berkontribusi adalah vasodilatasi, hipotensi, berkurangnya deformabilitas eritrosit, dan trombosis mikrovaskular, yang akhirnya menyebabkan berkurangnya hantaran oksigen pada syok septik. Berkurangnya oksigenasi jaringan makin diperberat oleh hilangnya integritas endotel karena beberapa faktor, yaitu hilangnya fungsi molekul adhesi vascular 
endothelial (VE) chaderin pada sambungan antar sel endotel, gangguan keseimbangan sphingosine-1 phosphate receptor 1 (S1P1) dan S1P3 (yang berperan pada struktur sel endotel) karena aktivasi protease activated receptors (PARs), dan meningkatnya kadar angiopoietin 2 (faktor proangiogenik). Rusaknya mitokondria oleh stres oksidatif juga mengganggu penggunaan oksigen selular. Selain itu, mitokondria yang cedera melepaskan DAMPs ke lingkungan ekstrasel, yang dapat mengaktivasi respon imun jaringan dan menyebabkan kerusakan lebih lanjut. ${ }^{4}$ Modifikasi komponen membran eritrosit seperti protein, lipid, dan karbohidrat menyebabkan terjadi penurunan deformabilitas eritrosit pada sepsis. Modifikasi komponen protein berupa peningkatan rasio band-3/ $\alpha$-spectrin menyebabkan perubahan struktur integral membran. Pada komponen lipid, terjadi pembentukan seramid membran yang menyebabkan peningkatan konsentrasi $\mathrm{Ca}^{2+}$ intrasel dan selanjutnya merangsang kanal $\mathrm{K}^{+}-\mathrm{Ca}^{2+}$ dan kanal $\mathrm{Cl}^{-}$,'sehingga $\mathrm{KCl}$ akan keluar dari sel, dan akibatnya terjadi dehidrasi sel. ${ }^{23}$

Umumnya paru-paru merupakan organ yang pertama terlibat, mulai dari disfungsi ringan sampai sindrom gagal nafas akut (acute respiratory distress syndrome ARDS). Hal ini diduga disebabkan oleh kebocoran kapiler sehingga alveolar terisi cairan, dan deaktivasi surfaktan. Organ kedua ialah miokardium, disebabkan terutama oleh peningkatan sintesis NO. Otak sering terpengaruh pada MODS awal, dengan mekanisme penyebab yang multifaktorial dan melibatkan gangguan sawar darah-otak, dengan peningkatan permeabilitas terhadap sitokin dan neuroamin. Disfungsi hati akut yang sering terjadi saat penurunan perfusi selama syok, biasanya reversibel setelah resusitasi, namun setelah periode laten, disfungsi hati ireversibel dapat terjadi. Katekolamin dari usus, terutama norepinefrin, diduga menginduksi kegagalan hati. Ginjal dianggap dapat mempertahankan perfusi selama sepsis dan mekanisme kegagalan ginjal selama MODS disebabkan terutama oleh apoptosis yang diinduksi sitokin. ${ }^{22}$

\section{Simpulan}

Sepsis adalah mekanisme kompleks yang dapat meliputi patogen penyebab infeksi dengan faktor virulensinya, respon pejamu, respon inflamasi, sistem koagulasi yang terganggu, dan disfungsi organ. Kompleksnya perubahan imunopatologi dan sistem koagulasi bertangung jawab terhadap morbiditas dan mortalitas pasien sepsis dan syok septik. Definisi dan kriteria klinis yang diperbarui diharapkan dapat memfasilitasi penatalaksanaan pasien berisiko sepsis dengan lebih tepat waktu.

\section{Daftar Pustaka}

1. Mayr FB, Yende S, Angus DC. Epidemiology of severe sepsis. Virulence 2014;5(1):4-11.

2. Jawad I, Luksic I, Snorri, Rafnsson B. Assessing available information on the burden of sepsis: global estimates of incidence, prevalence, and mortality. J of Glob Health. 2012;2(1):1-9.

3. Kumar A, Roberts D, Wood KE, Light B, Parrillo JE, Sharma S, et al. Duration of hypotension before initiation of effective antimicrobial therapy is the critical determinant of survival in human septic shock. Crit Care Med. 2006;34:1589-96.

4. Hotchkiss RS, Moldawer LL, Opal SM, Reinhart K, Turnbull IR, Vincent JL. Sepsis and septic shock. Nature Rev. 2016;2:1-20.

5. Levy MM, Fink MP, Marshall JC, Abraham E, Angus D, Cook D, et al. $2001 \mathrm{SCCM} / \mathrm{ESICM} / \mathrm{ACCP} / \mathrm{ATS} / \mathrm{SIS}$ International sepsis definitions conference. Intensive Care Med. 2003; 29:530-8.

6. Singer M, Deutschman CS, Seymour CW, Shankar-Hari M, Annane D, Bauer $\mathbf{M}$, et al. The third international consensus definitions for sepsis and septic shock (sepsis-3). JAMA. 2016; 315:801-10.

7. Munford RS. Severe sepsis and septic shock. In: Kasper DL, Fauci AS, Longo DL, Baunwalda E, Hauser SL, Jameson JL, editors. Harrison's Principle of Internal Medicine (17th ed). New York: Mc Graw Hill, 2008 p. 1695-702.

8. Angus DC, van der Poll T. Severe sepsis and septic shock. N Engl J Med. 2013; 
369:840-51

9. Mahon CR, Mahlen S. Host-parasite interaction. In: Mahon CR, Lehman DC, Manuselis G, editors. Textbook of Diagnostic Microbiology (5th ed). Missouri: Saunders Elsevier, 2015; p. 23-46.

10. Winn WC, Koneman EW. Medical bacteriology: taxonomy, morphology, physiology, and virulence. In: Winn WC, Koneman EW, Allen SD, Procop GW, Schreckenberger PC, Janda WM, et al, editors. Koneman's Color Atlas and Textbook of Diagnostic Microbiology (6th ed). Philadelphia: Lippincott Williams and Wilkins, 2005; p. 167-207.

11. Abbas AK, Licthman AH, Pillai S. Immunity to microbes. In: Abbas AK, Licthman AH, Pillai S, editors. Cellular and Molecular Immunology (7th ed). Philadelphia: Elsevier, 2012; p. 339-57.

12. Abbas AK, Licthman AH, Pillai S. Innate immunity. In: Abbas AK, Licthman $\mathrm{AH}$, Pillai S, editors. Cellular and Molecular Immunology (7th ed). Philadelphia: Elsevier, 2012; p. 51-86.

13. Sagy M, Al-Qaqaa Y, Kim P. Definition and pathophysiology of sepsis. Curr Probl Pediatr Adolesc Health Care. 2013; 43:260-3.

14. MacIsaac CM, Curtis N, Cade J, Visvanathan K. Superantigens in sepsis. Int Congr Ser. 2006;1289:121-4.

15. Russell JA. Management of sepsis. N Engl J Med. 2006;355:1699-707.
16. King EG, Bauza GJ, Mella JR, Remick DG. Pathophysiologic mechanism in septic shock. Lab Invest. 2014;94:4-12.

17. Nickel KF, Renné T. Crosstalk of the plasma contact system with bacteria. Thromb Res. 2012;130:S78-83.

18. Joyce DE, Gelbert L, Ciaccia A, DeHoff B, Grinnell BW. Gene expression profile of antithrombotic protein $\mathrm{C}$ defines new mechanisms modulating inflammation and apoptosis. J Biol Chem 2001; 276:11199-203.

19. Grinnell BW, Hermann RB, Yan SB. Human protein $\mathrm{C}$ inhibits selectinmediated cell adhesion: role of unique fucosylated oligosaccharide. Glycobiology. 1994;4:221-5.

20. Neyrinck AP, Liu KD, Howard JP, Matthay MA. Protective mechanisms of activated protein $\mathrm{C}$ in severe inflammatory disorders. Br J Pharmacol. 2009;158: 1034-47.

21. Oesman F, Setiabudy RD. Fisiologi hemostasis dan fibrinolisis. In: Setiabudy RD, editor. Hemostasis dan Trombosis (5th ed). Jakarta: Balai Penerbit FKUI, 2012; p.1-15.

22. Ramirez M. Multi organ dysfunction syndrome. Curr Probl Pediatr Adolesc Health Care. 2013;43:273-7.

23. Serroukh Y, Djebara S, Lelubre C, Boudjeltia KZ, Biston P, Piagnerelli M. Alterations of the erythrocyte membrane during sepsis. Crit Care Res Pract. 2012;702956:1-7. 